Акімова Людмила Миколаївна, кандидат економічних наук, доцент, доцент кафедри фінансів іприродокористування, Національний університет водного господарства та природокористування, 33000, м. Рівне, вул. Олекси Новака, 75, тел.: (067) 36223 91, e-mail:__akimova@ ukr.net

ORCID: 0000-0002-2747-2775

Акимова Людмила Николаевна, кандидат экономических наук, доцент, дочент кафедры финансов и природопользования, Национальный университет водного хозяйства и природопользования, 33000 г. Ровно, ул. Алексея Новака, 75, тел.: (067) 36223 91, e-mail:__akimova@ ukr.net

ORCID: 0000-0002-2747-2775

Akimova Lyudmila Nikolayevna,

PhD of economic science, assistant professor, assistant professor of the Department of finance and environmental sciences, National University of Water and Environment, 33000, Rivne, Str. Oleksy Novaka, 75, tel.: (067) 36223 91,e-mail:__akimova@ukr.net

ORCID: 0000-0002-2747-2775

DOI: $10.32689 / 2617-2224-2018-15-5-15-29$

\title{
ІНСТИТУЦІї ДЕРЖАВНОГО РЕГУЛЮВАННЯ ПРОТИДІї КОРУПЦІї У СИСТЕМІ ЗАБЕЗПЕЧЕННЯ ЕКОНОМІЧНОЇ БЕЗПЕКИ УКРАЇНИ
}

Анотація. Надано дефініції поняттям “економічна безпека” та “державне регулювання”. Під економічною безпекою держави варто розуміти багатофакторну систему, головна мета якої - забезпечення сталого економічного розвитку від негативного зовнішнього та внутрішнього впливу. Доведено, що державне регулювання економіки становить цілеспрямований та активний вплив державних та наддержавних органів управління на функціонування та розвиток цілісної економічної системи.

Визначено інституції державного регулювання, через які здійснюється вплив на економічну безпеку країни. Схарактеризовано основні принципи та методи державного регулювання. Встановлено, що принципи державного регулювання економіки реалізовуються через певні методи, які становлять сукупність конкретних регулюючих засобів впливу на заінте- 
ресований об'єкт для вирішення конкретно поставлених завдань. Методи мають певний статус обов'язковості для застосування і демонструють закономірності державно-регуляторних відносин. Крім того, наведено класифікацію методів державного регулювання, яка включає прямі, непрямі, правові, адміністративні та економічні методи.

Визначена правова основа здійснення державного регулювання в забезпеченні економічної безпеки держави, яка передбачає прийняття законів і законодавчих актів Верховної Ради України, видання указів Президента, а також вироблення механізму їх реалізації та контролю. Схарактеризовано нормативно-правове регулювання забезпечення економічної безпеки держави. Встановлено, що окрім методів державного регулювання протидії корупції у сфері економічної безпеки України присутні суб'єкти, які керуються відповідними нормативно-правовими актами. Досліджено роль державних органів у запобіганні корупції в Україні.

Ключові слова: економічна безпека, державне регулювання, принцип ефективності, принцип справедливості, принцип системності, принцип адекватності.

\section{ИНСТИТУЦИИ ГОСУДАРСТВЕННОГО РЕГУЛИРОВАНИЯ ПРОТИВОДЕЙСТВИЯ КОРРУПЦИИ В СИСТЕМЕ ОБЕСПЕЧЕНИЯ ЭКОНОМИЧЕСКОЙ БЕЗОПАСНОСТИ УКРАИНЫ}

Аннотация: Представлены дефиниции понятиям “экономическая безопасность” и “государственное регулирование”. Под экономической безопасностью государства следует понимать многофакторную систему, главной целью которой является обеспечение устойчивого экономического развития от негативного внешнего и внутреннего воздействия.

Доказано, что государственное регулирование экономики представляет собой целенаправленное и активное воздействие государственных и надгосударственных органов управления на функционирование и развитие целостной экономической системы.

Определены институции государственного регулирования, через которые осуществляется влияние на экономическую безопасность страны. Охарактеризованы основные принципы и методы государственного регулирования. Установлено, что принципы государственного регулирования экономики реализуются через определенные методы, представляющие собой совокупность конкретных регулирующих средств воздействия на заинтересованный объект для решения конкретно поставленных задач. Методы имеют определенный статус обязательности для применения и они демонстрируют закономерности государственно-регуляторных отношений. Кроме того, приведена классификация методов государственного регулирования, которая включает прямые, косвенные, правовые, административные и экономические методы. 
Определена правовая основа осуществления государственного регулирования в обеспечении экономической безопасности государства. Она предполагает принятие законов и законодательных актов Верховной Рады Украины, издание указов Президента, а также выработка механизма их реализации и контроля. Охарактеризовано нормативно-правовое регулирование обеспечения экономической безопасности государства. Установлено, что кроме методов государственного регулирования противодействия коррупции в сфере экономической безопасности Украины присутствуют субъекты, руководствующиеся соответствующими нормативно-правовыми актами. Исследована роль государственных органов в предупреждении коррупции в Украине.

Ключевые слова: экономическая безопасность, государственное регулирование, принцип эффективности, принцип справедливости, принцип системности, принцип адекватности.

\section{INSTITUTIONS OF STATE REGULATION OF CORRUPTION ACTIVITIES IN THE SYSTEM OF ENSURING ECONOMIC SECURITY OF UKRAINE}

Abstract. The definitions of "economic security" and "state regulation" are given. In our opinion, under the economic security of the state, one should understand the multifactorial system, the main purpose of which is to ensure sustainable economic development from negative external and internal influence. It is proved that state regulation of the economy is a deliberate and active influence of state and supranational authorities on the functioning and development of of an integral economic system.

The institutions of state regulation, through which influence on economic safety of the country is carried out, is defined. The main principles and methods of state regulation are characterized. It is established that the principles of state regulation of the economy are realized through certain methods, which constitute a set of specific regulatory means of influence on the object of interest for solving concrete tasks. The methods have a certain status of compulsory use, they show us the patterns of state-regulatory relations. In addition, the classification of methods of state regulation, which includes direct, indirect, legal, administrative and economic methods, is given.

The legal basis for the implementation of state regulation in ensuring the economic security of the state is determined. It involves the adoption of laws and legislative acts of the Verkhovna Rada of Ukraine, the issuance of presidential decrees, as well as the elaboration of a mechanism for their implementation and control. Characterized regulatory and legal regulation of ensuring economic security of the state. It is established, in addition to the methods of state regulation of combating corruption in the sphere of economic security of Ukraine, there are entities that are guided by the relevant regulatory and legal acts. The role of state bodies in preventing corruption in Ukraine is investigated.

Keywords: economic security, state regulation, the principle of efficiency, the principle of justice, the principle of system, the principle of adequacy. 
Постановка проблеми. У сучасних умовах ринкових трансформацій важливим аспектом формування стабільної правової держави зі сталим економічним розвитком є наявність механізму запобігання та протидії корупції. Досягнення успіху в цьому процесі є важливою передумовою у формуванні суспільної довіри до влади, зростання економічного потенціалу держави, покращення добробуту громадян України. Корупція в усіх іiї виявах становить реальну загрозу економічній безпеці держави, при цьому знижуючи іï конкурентоспроможність. Для врегулювання означеного процесу держава здійснює безпосередній вплив на знищення корупції та захист економічної безпеки держави.

Аналіз останніх досліджень i публікацій. Дослідження механізму державного регулювання протидії корупції у системі забезпечення економічної безпеки України знайшли своє відображення у працях таких науковців, як: О. Барановський, П. Бернацький, К. Бліщук, Э. Бухвальд, А. Васіна, Л. Герасименко, I. Губарєва, М. Дзюбенко, Т. Желюк, Г. Калетнік, О. Користін, О. Кубай, С. Лазаренко, А. Мазур, А. Мельник, С. Мочерний, С. Онишко, М. Пендюра, Т. Попович, Т. Поснова, Н. Словацкая, Г. Старостенко, В. Тамбовцев, Г. Третяк.

Мета статті - розкрити сутність понять “економічна безпека" та "державне регулювання економіки”; визначити основні складові механізму державного регулювання економіки; схарактеризувати принципи державного регулювання; визначити методи державного регулювання; схаракте- ризувати нормативно-правове регулювання забезпечення економічної безпеки держави; дослідити роль державних органів у запобіганні корупції в Україні.

\section{Виклад основного матеріалу.} Економічна безпека держави є багатофункціональною та багатоплановою категорією, яка впливає на всі сфери суспільного життя. Досвід багатьох країн світу демонструє нам, що тільки надійний та ефективний механізм забезпечення економічної безпеки може виступати гарантом суверенітету та незалежності країни, іiї стійкого та стабільного соціальноекономічного розвитку. Саме через важливість цього питання, для кращого розуміння даної тематики, варто надати дефініції поняттю "економічна безпека".

Науковці Г. Старостенко, С. Онишко та Т. Поснова стверджують, що економічна безпека - це складна багатофакторна динамічна система, що виражається в її масштабах, структурі і технічному рівні, за яких вона здатна створювати матеріальні та фінансові ресурси, що є достатніми, по-перше, для захисту національних інтересів у внутрішньополітичній, міжнародній, інформаційній, екологічній сферах, а також у сфері здоров'я людей, захисту від тероризму, корупції тощо, а по-друге, для забезпечення рівня та якості життя населення, що гарантуе можливість підтримки соціального миру та суспільної стабільності, а також створює умови для економічного зростання [1].

На думку С. Тамбовцева, під економічною безпекою будь-якої системи необхідно розуміти сукупність 
властивостей стану ㄲi виробничої підсистеми, що забезпечує можливість досягнення цілей усієї системи [2].

Однак О. Користін вважає, що економічну безпеку варто трактувати як забезпечення здатності до виживання країни у випадку стихійних і екологічних лих або за умов національних і світових економічних катастроф [3].

Науковець М. Пендюра зазначає, що економічна безпека держави є не тільки однією з найважливіших складових цілісної системи національної безпеки як комплексу захисту національних інтересів, а й вирішальною умовою дотримання і реалізаціі національних інтересів [4, с. 13].

Дослідники Е. Бухвальд, Н. Головацька, С. Лазуренко пропонують розглядати економічну безпеку держави як найважливішу якісну характеристику економічної системи, i визначальну здатність підтримувати нормальні умови життедіяльності населення, стійке забезпечення ресурсами розвитку народного господарства [5, с. 27].

На нашу думку, під економічною безпекою держави варто розуміти багатофакторну систему, головною метою якої є забезпечення сталого економічного розвитку від негативного зовнішнього та внутрішнього впливу. Зважаючи на важливість та необхідність цього питання, державне регулювання є невід'ємною умовою нормального та безперебійного функціонування економічної безпеки країни.

Отже, державне регулювання економіки - це цілеспрямований та активний вплив державних та над- державних органів управління на функціонування та розвиток цілісної економічної системи (тобто на iii розширене відтворення) шляхом використання економічних законів i вирішення економічних суперечностей за допомогою певної сукупності форм і методів [6].

Такий вплив здійснюється через певний механізм державного регулювання, який включає в себе наступні основні складові: цілі, завдання, принципи, функції, суб'єкти й об'єкти, методи, форми державного регулювання. Для недопущення безсистемного та руйнівного втручання в економічний механізм господарювання державне регулювання грунтується на принципах, наведених на рис. 1.

Тобто з цього рисунка випливає, що до принципів державного регулювання належать:

- ефективність - передбачає кінцевий економічний ефект, нейтралізацію монополій та циклічності, раціональну податкову політику;

- справедливість - коригування системи перерозподілу, матеріальних благ з метою запобігання різкому розшаруванню суспільства за доходами;

- пріоритет права над економікою - відповідним законодавчим регулюванням здійснюється трансформація державної власності у приватну, формується клас підприємців та створюється відповідний базис ринкових відносин;

- стабільність - забезпечує вирівнювання підйомів і спадів ділового циклу, створення додаткових робочих місць, підтримку економічного зростання на тривалий період; 


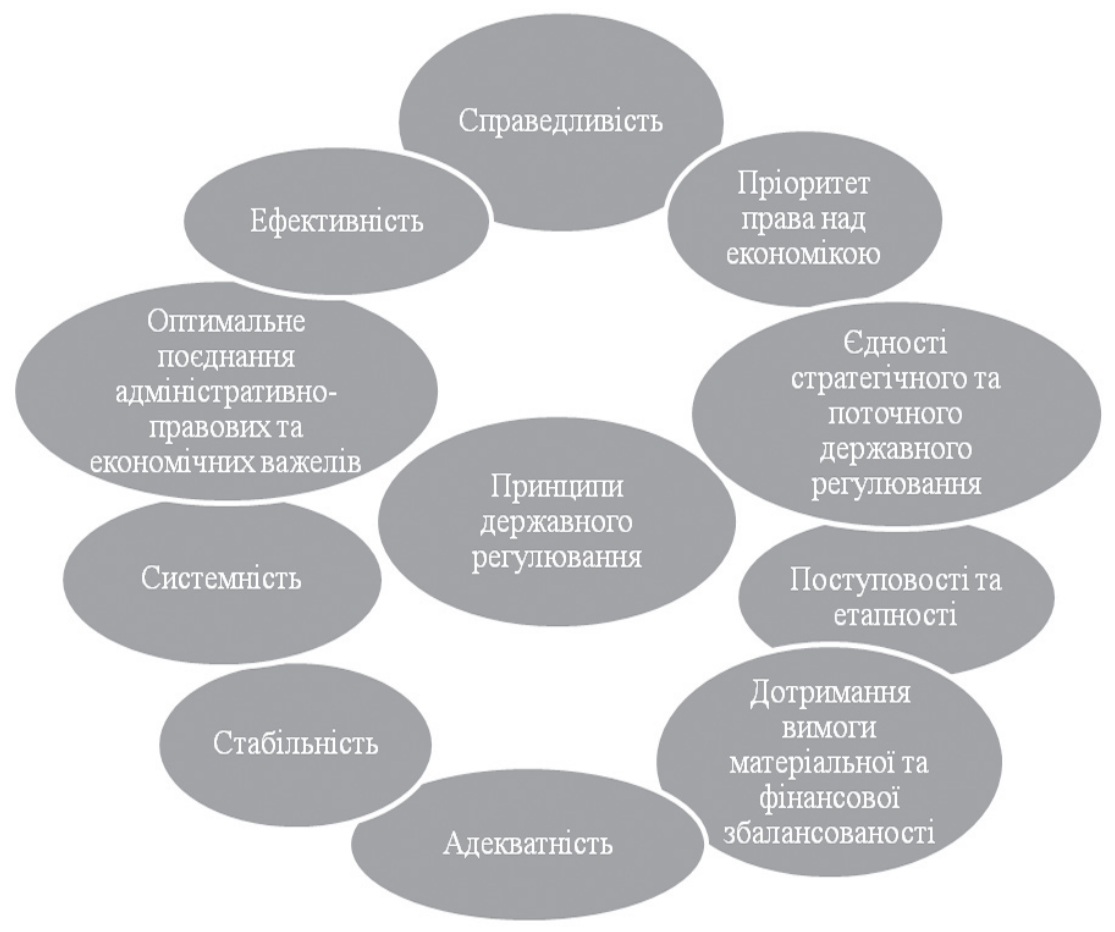

Рис. 1. Принципи державного регулювання

Складено автором на основі джерела [7]

- системність - передбачає всебічний підхід до розв’язання економічних, соціальних, зовнішньоекономічних та інших завдань;

- адекватність - означає, що система державного регулювання економіки та засоби її застосування мають відповідати реаліям конкретного етапу соціально-економічного розвитку держави, враховувати іiі інтереси в контексті тенденцій у змінах регіональних та світових ринків;

- оптимального поєднання адміністративно-правового і економічних важелів - гарантує на макроекономічному рівні формування раціональної структури виробництва;

- поступовості та поетапності вимагає при переході від адміністративно-командної до нової системи державного регулювання введення економічних регуляторів у міру того, які будуть створені об'єктивні передумови, насамперед, для завершення процесів роздержавлення, приватизації та макроекономічної стабілізації;

- єдності стратегічного і поточного державного регулювання - забезпечує можливість дотримання економічного і соціального стратегічного курсу, який передбачається державними, галузевими, науково-технічними та іншими програмами;

- дотримання вимоги матеріальної і фінансової збалансованості забезпечує реальність регулятивних заходів з позицій наявного ресурсного потенціалу суспільства [7].

Принципи державного регулювання економіки реалізовуються через певні методи, які становлять 
сукупність конкретних регулюючих засобів впливу на заінтересований об'єкт для вирішення конкретно поставлених завдань. Методи мають певний статус обов'язковості для застосування і демонструють закономірності державно-регуляторних відносин (рис. 2).

Як відображено на рис. 2, методи державного регулювання залежно від класифікаційних ознак поділяються:

- за засобами впливу на суб'єкти ринку:

- прямі - використовують з метою безпосереднього втручання держави в економічні процеси та економічну діяльність суб'єктів [8];

- непрямі - ціни, митне регулювання, пільги, оподаткування, валютні обмеження;

- залежно від засобів впливу на ринок:

- правові - передбачають прийняття законів і законодавчих актів Верховної Ради України, видання указів Президента, а також вироблення механізму їх реалізації та контролю [9, c. 311];

- адміністративні - методи прямого впливу, які безпосередньо діють на функціонування суб'єктів ринку. До них належать: визначення стратегічних цілей розвитку економіки та їх відображення в індикативних та інших планах, цільових програмах; державні замовлення й контракти на постачання певних видів продукції, виконання робіт, надання послуг; державна підтримка програм, замовлень і контрактів; нормативні вимоги до якості й сертифікації технології та продукції; правові й адміністративні обмеження та заборони щодо виробництва певних видів продукції; ліцензування операцій з експорту та імпорту товарів [10, с. 21];

- економічні - це система прийомів і способів прямого впливу на суспільно-господарський розвиток. До економічних методів регулювання належать: прогнозування, планування,

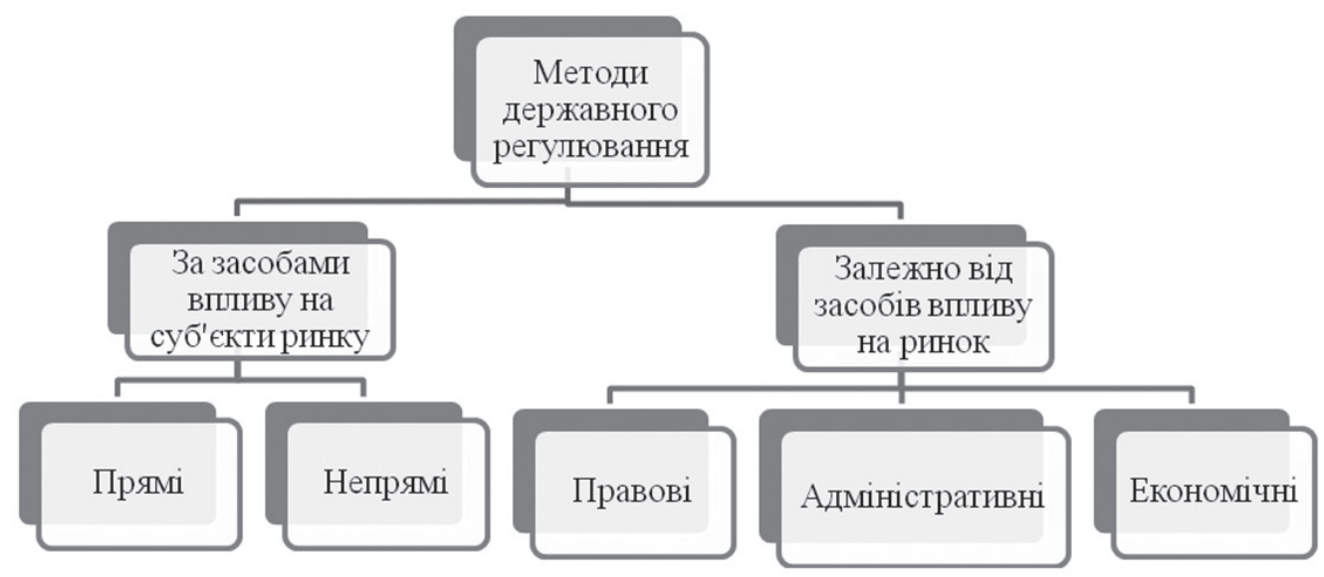

Рис. 2. Методи державного регулювання

Складено автором на основі джерела [7] 
програмування, матеріальне стимулювання та санкції, фінансування й кредитування тощо [9, с. 311].

Ми вважаємо, що доцільно розглянути саме правові методи, оскільки вони становлять правову основу забезпечення економічної безпеки держави. До них належать:

- Конституція України;

- Кодекси України (Кримінальний, Кримінальний процесуальний, “Про кримінальні правопорушення");

- Закони України ("Про внесення змін до деяких законодавчих актів України щодо відповідальності за корупційні правопорушення”, “Про очищення влади”, “Про запобігання корупціi”, “Про Національне антикорупційне бюро України”, “Про державну службу");

- Укази Президента України ("Про Національну раду 3 питань антикорупційної політики”, “Питання Ради громадського контролю при Національному антикорупційному бюро України”);

- Постанови Кабінету Міністрів України;

- накази міністерств.

Конституція України - регулює відносини у сфері господарювання, зокрема, відповідно до ст. 18 зовнішньополітична діяльність України спрямована на забезпечення ㄲï національних інтересів і безпеки шляхом підтримання мирного і взаємовигідного співробітництва з членами міжнародного співтовариства за загальновизнаними принципами і нормами міжнародного права [11; 27-29].

Кримінальний кодекс України (далі - ККУ) має своїм завданням правове забезпечення охорони прав i свобод людини i громадянина, власності, громадського порядку та громадської безпеки, довкілля, конституційного устрою України від злочинних посягань, забезпечення миру і безпеки людства, а також запобігання злочинам. Відповідно до ст. 354 ККУ пропозиція чи обіцянка працівникові підприємства, установи чи організації, який не є службовою особою, або особі, яка працюе на користь підприємства, установи чи організації, надати йому (ій) або третій особі неправомірну вигоду, а так само надання такої вигоди за вчинення чи не вчинення працівником будь-яких дій з використанням становища, яке він займає, або особою, яка працює на користь підприємства, установи чи організації, в інтересах того, хто пропонує, обіцяє чи надає таку вигоду, або в інтересах третьої особи - караються штрафом від ста до двохсот п'ятдесяти неоподатковуваних мінімумів доходів громадян або громадськими роботами на строк до ста годин, або виправними роботами на строк до одного року, або обмеженням волі на строк до двох років, або позбавленням волі на той самий строк [12].

Відповідно до ст. 131 Кримінально процесуального кодексу України (далі - КпКУ) заходами забезпечення кримінального провадження є: виклик слідчим, прокурором, судовий виклик і привід; накладення грошового стягнення; тимчасове обмеження у користуванні спеціальним правом; відсторонення від посади; тимчасове відсторонення судді від здійснення правосуддя; тимчасовий доступ до речей і документів; тимча- 
сове вилучення майна; арешт майна; затримання особи; запобіжні заходи [13].

У ст. 1 Кодексу України про адміністративні правопорушення (далі - КУпАП) зазначено, що завданням цього документа є охорона прав і свобод громадян, власності, конституційного ладу України, прав i законних інтересів підприємств, установ і організацій, встановленого правопорядку, зміцнення законності, запобігання правопорушенням, виховання громадян у дусі точного i неухильного додержання Конституції і законів України, поваги до прав, честі і гідності інших громадян, до правил співжиття, сумлінного виконання своїх обов’язків, відповідальності перед суспільством. Відповідно до ст. 172 цього документа зазначено, що порушення встановлених законом обмежень щодо одержання подарунків - тягне за собою накладення штрафу від ста до двохсот неоподатковуваних мінімумів доходів громадян з конфіскацією такого подарунка [14].

Крім того, відповідно до ст. 38 Закону України “Про внесення змін до деяких законодавчих актів України щодо відповідальності за корупційні правопорушення” зазначено, що порушення особою встановлених законом обмежень щодо використання службових повноважень та пов'язаних 3 цим можливостей з одержанням за це неправомірної вигоди у розмірі, що не перевищує ста неоподатковуваних мінімумів доходів громадян, або у зв'язку з прийняттям обіцянки/пропозиції такої вигоди для себе чи інших осіб - тягне за собою накладення штрафу від ста п’ятдесяти до п’ятисот неоподатковуваних мінімумів доходів громадян з конфіскацією незаконно одержаної неправомірної вигоди матеріального характеру [15].

Згідно із Законом України “Про очищення влади” у ст. 1 зазначено, що очищення влади (люстрація) - це встановлена цим Законом або рішенням суду заборона окремим фізичним особам обіймати певні посади (перебувати на службі) (далі - посади) (крім виборних посад) в органах державної влади та органах місцевого самоврядування [16].

Відповідно до Закону України “Про запобігання корупціï” в ст. 4 зазначено, що Національне агентство 3 питань запобігання корупції (далі Національне агентство) є центральним органом виконавчої влади зі спеціальним статусом, який забезпечує формування та реалізує державну антикорупційну політику [17].

У ст. 16 Закону України “Про Національне антикорупційне бюро України” зазначено, що Національне бюро: здійснює оперативно-розшукові заходи з метою попередження, виявлення, припинення та розкриття кримінальних правопорушень, віднесених законом до його підслідності, а також в оперативно-розшукових справах, витребуваних від інших правоохоронних органів; проводить досудове розслідування кримінальних правопорушень, віднесених законом до його підслідності, а також досудове розслідування інших кримінальних правопорушень у випадках, визначених законом; вживає заходів щодо розшуку та арешту коштів та іншого майна, які можуть бути предметом конфіскації або спе- 
ціальної конфіскації у кримінальних правопорушеннях, віднесених до підслідності Національного бюро, діє щодо зберігання коштів та іншого майна, на яке накладено арешт; взаємодіє з іншими державними органами, органами місцевого самоврядування та іншими суб'єктами для виконання своїх обов'язків; здійснює інформаційно-аналітичну роботу 3 метою виявлення та усунення причин і умов, що сприяють вчиненню кримінальних правопорушень, віднесених до підслідності Національного бюро; забезпечує особисту безпеку працівників Національного бюро та інших визначених законом осіб, захист від протиправних посягань на осіб, які беруть участь у кримінальному судочинстві, у підслідних йому кримінальних правопорушеннях; забезпечує на умовах конфіденційності та добровільності співпрацю з особами, які повідомляють про корупційні правопорушення; звітує про свою діяльність у порядку, визначеному цим Законом, та інформує суспільство про результати своєї роботи; здійснює міжнародне співробітництво у межах своєї компетенції відповідно до законодавства України та міжнародних договорів України [18].

Згідно зі ст. 8 п. 9 Закону України “Про державну службу" державний службовець повинен додержуватися вимог законодавства у сфері запобігання і протидії корупції [19].

Відповідно до Указу Президента України "Про Національну раду 3 питань антикорупційної політики” зазначено, що Національна рада відповідно до покладених на неї основних завдань: комплексно оцінює ситуації і тенденції у сфері запобіган- ня і протидії корупції в Україні, аналізує національне антикорупційне законодавство та заходи щодо його виконання; здійснюе моніторинг та аналіз ефективності реалізації антикорупційної стратегії, вносить пропозиції щодо поліпшення взаємодії органів, відповідальних за іiі імплементацію; бере участь у підготовці для внесення Президентом України на розгляд Верховної Ради України законопроектів у сфері запобігання і протидії корупції; готує пропозиції щодо законопроектів, проектів інших нормативно-правових актів у сфері запобігання і протидії корупції; бере участь у підготовці послань Президента України до народу, щорічних і позачергових послань до Верховної Ради України про внутрішне і зовнішне становище України в частині реалізації антикорупційної політики; організовує вивчення громадської думки 3 питань, що розглядаються Національною радою, забезпечує висвітлення у засобах масової інформації результатів своєї роботи; сприяє науково-методичному забезпеченню 3 питань запобігання і протидії корупції, проведенню аналітичних досліджень, розробленню методичних рекомендацій у цій сфері; готує пропозиції щодо підвищення ефективності міжнародного співробітництва України у сфері запобігання і протидії корупції [20].

Згідно з Указом Президента України "Питання Ради громадського контролю при Національному антикорупційному бюро України” зазначено, що основними завданнями Ради громадського контролю є: здійснення цивільного контролю за діяльністю Національного антико- 
рупційного бюро України; сприяння взаємодії Національного антикорупційного бюро України з громадськими об'єднаннями, іншими інститутами громадянського суспільства у сфері протидії корупції [21].

Окрім методів державного регулювання протидії корупції у сфері економічної безпеки України присутні суб’єкти, які керуються відповідними нормативно-правовими актами. До основних суб’єктів належать:

- органи прокуратури здійснюють нагляд за досудовим розслідуванням, підтримування державного обвинувачення в суді [22];

- служба безпеки України проводить виявлення корупційних злочинів і направлення їх на розслідування слідчим органам [23];

- генеральна інспекція внутрішніх розслідувань здійснює повноваження щодо досудового розслідування кримінальних правопорушень, вчинених прокурорами, проведення службових розслідувань щодо прокурорів та працівників органів прокуратури [24];

- вищий антикорупційний суд здійснює правосуддя відповідно до визначених законом засад та процедур судочинства 3 метою захисту особи, суспільства та держави від корупційних і пов'язаних із ними злочинами та судовий контроль за досудовим розслідуванням цих злочинів, дотриманням прав, свобод та інтересів осіб у кримінальному провадженні [25];

- поліція здійснюе розслідування дрібних корупційних злочинів, корупційних адміністративних правопорушень [26].
Отже, з проведеного дослідження ми бачимо, що на сьогодні відсутній злагоджений механізм щодо державного регулювання протидії корупції в економічній сфері, що, своєю чергою, призводить до зниження антикорупційної діяльності в країні. Звісно, варто зауважити, що створене відповідне нормативно-правове забезпечення цього питання, існують суб'єкти, які є компетентними в даному питанні, але все одно методи та покарання за вчинення злочинів у сфері економічної безпеки мають бути більш жорсткі та справедливі.

\section{СПИСОК ВИКОРИСТАНИХ ДЖЕРЕЛ}

1. Старостенко $Г$. Національна економіка: навч. посіб. [Електронний ресурс]/Г. Старостенко, С. Онишко, Т. Поснова. - К. : Ліра-К, 2011. Режим доступу: http://pidruchniki. com/1344061444697/ekonomika/ natsionalna_ekonomika_ekonomichna_bezpeka

2. Тамбовцев В. Экономическая безопасность хозяйсвенных систем: структура, проблемы / В. Тамбовцев // Весн. МГУ. - Сер. 6. Экономика. - 1995. - № 3. - С. 3.

3. Користін О. Економічна безпека: навч. посіб. [Електронний ресурс] / [О. Користін, О. Барановський, Л. Герасименко та ін.]; за ред. О. Джужі. - К. : Алерта; КНТ; Центр учб. л-ри, 2010. - Режим доступу: http:// libfree.com/101560472_ekonomikateoretichni_zasadi_ek̄onomichnoyi_bezpeki.html\#127

4. Пендъюра M. Національна безпека України в контекстів сучасних європейських геополітичних трансформацій : дис. ... канд. юрид. наук: спец. 12.00.01 / М. М. Пендюра. - К.: [б. в.], 2005. -212 c. 
5. Бухвальд Э. Макроаспекты экономической безопасности: факторы, критерии и показатели / Э. Бухвальд, Н. Словацкая, С. Лазаренко // Вопр. экономики. - 1994. - № 12. C. 25-44.

6. Мочерний B. С. Економічна теорія [Електронний ресурс] : посібник / С. В. Мочерний, М. В. Дзюбенко. Режим доступу: http://pidruchniki. com/ ekonomika/derzhavne_regulyuvannya_ekonomiki

7. Калетнік Г. М. Державне регулювання економіки : навч. посіб. [Електронний ресурс] / Г. М. Калетнік, А. Г. Мазур, О. Г. Кубай. К. : Хай-Тек Пресс, 2011. - 428 с. Режим доступу: http://pidruchniki. com/ 1566052638685/ekonomika/ printsipi_metodi_derzhavnogo_regulyuvannya_ekonomiki

8. Мельник $A$. Ф. Національна економіка: навч. посіб. [Електронний ресурс] / А. Ф. Мельник, А. Ю. Васіна, Т. Л. Желюк, Т. М. Попович. - К.: 2011. - Режим доступу: h t t p : / / p i d r u c h n i k i. com/1157071841813/ekonomika/ metodi_derzhavnogo_regulyuvannya_ekonomiki

9. Губарєва I. О. Механізм державного регулювання протидії корупції у системі забезпечення економічної безпеки України / I. О. Губарєва, П. Й. Бернацький // Наук. вісн. Львів. держ. ун-ту внутр. справ. Сер. Економічна. - 2011. - Вип. 2. C. 307-314.

10. Третяк Г. С. Державне регулювання економіки та економічна політика [Текст]: навч. посіб. / Г. С. Третяк, К. М. Бліщук. - Л. : ЛРІДУ НАДУ, 2011. - $128 \mathrm{c}$.

11. Конституція України : прийнята на п'ятій сесії Верховної Ради України 28 червня. 1996 р. [Електронний ресурс]. - Режим доступу до pecypcy: http://zakon2.rada.gov.ua/
laws/show/254\%D0\%BA/96\%D0\% B2\%D1\%80/page4.

12. Кримінальний кодекс України від 05.04.2001 p. № 2341-III [Електронний ресурс] / / Верховна Рада України. - Режим доступу: http://zakon0. rada.gov.ua/laws/show/2341-14/page

13. Кримінальний процесуальний кодекс України від 13.04.2012 р. № 4651-VI [Електронний ресурс] // Верховна Рада України. - Режим доступу: http://zakon2.rada.gov.ua/ laws/show/4651-17

14. Кодекс України про адміністративні правопорушення від 07.12.1984 р. № 8073-Х [Електронний ресурс] // Верховна Рада України. - Режим доступу: http://zakon0.rada.gov.ua/ laws/show/80731-10/page

15. Закон України "Про внесення змін до деяких законодавчих актів України щодо відповідальності за корупційні правопорушення" від 07.04.2011 p. № 3207-VI [Електронний ресурс] // Верховна Рада України. - Режим доступу: http://zakon1. rada.gov.ua/laws/show/3207-17

16. Закон України "Про очищення влади” від 16.09.2014 р. № 1682-VII [Електронний ресурс] // Верховна Рада України. - Режим доступу: http://zakon4.rada.gov.ua/laws/ show/1682-18

17. Закон України "Про запобігання корупціі” від 14.10.2014 р. № 1700-VII [Електронний ресурс] // Верховна Рада України. - Режим доступу: http://zakon5.rada.gov.ua/laws / show/1700-18/print1469702127168206

18. Закон України “Про Національне антикорупційне бюро України” від 14.10.2014 p. № 1698-VII [Електронний ресурс] // Верховна Рада України. - Режим доступу: http:// zakon0.rada.gov.ua/laws/show/169818

19. Закон України "Про державну службу” від 10.12.2015 р. № 889-VIII 
[Електронний ресурс] // Верховна Рада України. - Режим доступу: http://zakon2.rada.gov.ua/laws/ show/889-19

20. Указ Президента України “Про Національну раду з питань антикорупційної політики” від 14.10.2014 р. № 808/2014 [Електронний peсурс] // Верховна Рада України. Режим доступу: http://zakon0. rada.gov.ua/laws / show/808/ 2014

21. Указ Президента України "Питання Ради громадського контролю при Національному антикорупційному бюро України” від 15.05.2015 р. № 272/2015 [Електронний peсурс] // Верховна Рада України. Режим доступу: http://zakon4.rada. gov.ua/laws/show/272/2015

22. Закон України "Про прокуратуру" від 14.10.2014 р. № 1697-VII [Електронний ресурс] // Верховна Рада України. - Режим доступу: http:// zakon5.rada.gov.ua/laws/show/169718.

23. Закон України "Про Службу безпеки України” від 25.03.1992 р. № 2229-XII [Електронний ресурс] // Верховна Рада України. - Режим доступу: http://zakon5.rada.gov.ua/ laws/show/2229-12

24. Офічійний сайт Генеральної прокуратури України [Електронний ресурс]. - Режим доступу: https:// www.gp.gov.ua

25. Закон України “Про Вищий антикорупційний суд” від 07.06.2018 р. № 2447-VIII [Електронний peсурс] // Верховна Рада України. Режим доступу: http://zakon5.rada. gov.ua/laws/show/2447-19

26. Закон України "Про Національну поліцію” від 02.07.2015 р. № 580VIII [Електронний ресурс] // Верховна Рада України. - Режим доступу: http://zakon3.rada.gov.ua/laws/ show/580-19
27. Акімова Л. М. Теоретичні основи державного управління розвитком національної безпеки / Л. М. Акімова // Держ. упр.: удосконалення та розвиток: електронне наукове фахове вид. - 2015. - № 5. - Режим доступу: http://www.dy.nayka.com. ua/?op $=1 \& z=1210$

28. Акімова Л. М. Етапи становлення економічної безпеки держави: зарубіжний та вітчизняний досвід / Л. М. Акімова // Держ. упр.: удосконалення та розвиток: електронне наукове фахове вид. 2016. - № 8. - Режим доступу: http:// www.dy.nayka.com.ua/?op $=1 \& z=$ 1246

29. Акімова Л. М. Сутнісна характеристика основних загроз в економічній безпеці держави / Л. М. Акімова // Держ. упр.: удосконалення та розвиток: електронне наукове фахове вид. - 2016. - № 10. - Режим доступу: http://www.dy.nayka.com. ua/?op $=1 \& z=1247$

\section{REFERENCES}

1. Starostenko G., Onyshko S., Podsnov T. (2011), Natsionalna ekonomika [National Economy], Lira, Kyiv, Ukraine.

2. Tambovtsev V. (1995), "Economic security of economic systems: structure, problems", Bulletin of MSU, Series 6 Economics, vol. 6, p. 3.

3. Korystin O., Baranovsky O., Gerasimenko L. (2010), Ekonomichna bezpeka [Economic Security], Center for Educational Literature, Kyiv, Ukraine.

4. Pendjura M. (2005), "National Security of Ukraine in the context of modern European geopolitical transformations", Ph.D. Thesis, Theory and history of state and law, Kyiv National University of Internal Affairs, Kyiv, Ukraine. 
5. Buchwald E., Slovatskaya N., Lazarenko S. (1994), "Macroaspects of economic security: factors, criteria and indicators", Pytannia ekonomiky, vol. 12, p. 25-44.

6. Mocherny S., Dzyubenko M. (1999), Ekonomichna teoriia [Economic theory], Academy, Kyiv, Ukraine.

7. Kaletnik G., Mazur A., Kubay, O. (2011), Derzhavne rehuliuvannia ekonomiky [State regulation of the economy], High-Tech Press, Kyiv, Uraine.

8. Melnik A., Vasina A., Zhelyuk T., Popovich T. (2011), Natsionalna ekonomika [National economy], Znannya, Kyiv, Ukraine.

9. Gubareva I., Bernatsky, P. (2011), "The mechanism of state regulation of combating corruption in the system of providing economic security of Ukraine”, Naukovyi visnyk Lvivskoho derzhavnoho universytetu vnutrishnikh sprav, vol. 2, p. 307-314.

10. Tretyak G., Blischuk K. (2011), Derzhavne rehuliuvannia ekonomiky ta ekonomichna polityka [State regulation of the economy and economic policy], LRIDU NADU, Lviv, Ukraine.

11. The Verkhoona Rada of Ukraine (1996), Constitution of Ukraine, available at: http://zakon2.rada.gov. ua/laws/show $/ 254 \%$ D0\%BA/96\% D0\%B2\%D1\% $80 /$ page4 (Accessed 28 June 2018).

12. The Verkhoona Rada of Ukraine (2001), Criminal Codex of Ukraine, available at: http://zakon0.rada.gov.ua/laws/ show/2341-14/page (Accessed 25 April 2018).

13. The Verkhowna Rada of Ukraine (2012), Criminal Procedural Codex of Ukraine, available at: http://zakon2.rada.gov. ua/laws/show/4651-17 (Accessed 23 April 2018).

14. The Verkhovna Rada of Ukraine (1984), The Code of Ukraine on Administrative Offenses, available at: http:// zakon0.rada.gov.ua/laws / show / 80731-10/page (Accessed 28 June 2018).

15. The Verkhowna Rada of Ukraine (2011), The Law of Ukraine "On amendments to some legislative acts of Ukraine concerning liability for corruption", available at: http://zakon1.rada.gov. ua/laws/show/3207-17 (Accessed 17 April 2018).

16. The Verkhowna Rada of Ukraine (2014), The Law of Ukraine "On purge of authorities”, available at: http://zakon4. rada.gov.ua/laws/show/1682-18 (Accessed 30 June 2018).

17. The Verkhoona Rada of Ukraine (2014), The Law of Ukraine "On Preventing Corruption”, available at: http:/ zakon5.rada.gov.ua/laws/show/170018/print1469702127168206 (Accessed 14 May 2018).

18. The Verkhowna Rada of Ukraine (2014), The Law of Ukraine "On National Anti-Corruption Bureau of Ukraine”, available at: http://zakon0.rada.gov. ua/laws/show/1698-18 (Accessed 16 May 2018).

19. The Verkhoona Rada of Ukraine (2015), The Law of Ukraine "On the civil service”, available at: http://zakon2.rada. gov.ua/laws/show/889-19 (Accessed 20 May 2018).

20. The Verkhoona Rada of Ukraine (2014), Decree of the President of Ukraine "On National Anti-Corruption Policy Council”, available at: http://zakon0. rada.gov.ua/ laws/show/808/2014 (Accessed 22 May 2018).

21. The Verkhovna Rada of Ukraine (2015), Decree of the President of Ukraine "Issues of the Public Control Council at the National Anti-Corruption Bureau of Ukraine", available at: http://zakon4. rada.gov.ua/laws/show/272/2015 (Accessed 15 May 2018).

22. The Verkhovna Rada of Ukraine (2014), The Law of Ukraine "On the Prosecutor's Office”, available at: http:// 
zakon5.rada.gov.ua/laws/show/169718 (Accessed 25 May 2018).

23. The Verkhovna Rada of Ukraine (1992), The Law of Ukraine "On the Security Service of Ukraine", available at: http://zakon5.rada.gov.ua/laws/ show/2229-12 (Accessed 23 March 1992).

24. Official website of the General Prosecutor's Office of Ukraine: https:// www.gp.gov.ua.

25. The Verkhovna Rada of Ukraine (2018), The Law of Ukraine "On the Supreme Anticorruption Court”, available at: http://zakon5.rada.gov.ua/laws / show/2447-19 (Accessed 7 June 2018).

26. The Verkhovna Rada of Ukraine (2015), The Law of Ukraine "On the National Police", available at: http://zakon3. rada.gov.ua/laws/show/580-19 (Accessed 2 July 2018).

27. Akimova L. M. (2015), "Theoretical Foundations of Public Administration for the Development of National Secu- rity", Public administration: improvement and development: an electronic scientific specialized publication, [Online], vol. 5, available at: http://www. dy.nayka.com.ua/?op=1\&z=1210 (Accessed 2 July 2018).

28. Akimova L.M. (2016), "Stages of formation of economic security of the state: foreign and domestic experience", Public administration: improvement and development: an electronic scientific specialized publication, [Online], vol. 8, available at: http://www.dy.nayka. com.ua/?op=1\&z=1246 (Accessed 5 July 2018).

29. Akimova L. M. (2016), "Essential characteristics of the main threats to the economic security of the state", Public administration: improvement and development: an electronic scientific specialized publication, [Online], vol. 10, available at: http://www.dy.nayka. com.ua/?op=1\&z=1247 (Accessed 10 July 2018). 